\title{
Assessment of Low-cost Postharvest Techniques to Reduce Storage Losses in Sweet Potato
}

\author{
Issah Sugri ${ }^{1}$, Bonaventure Kissinger Maalekuu ${ }^{2}$, Eli Gaveh ${ }^{2}$, Francis Kusi ${ }^{1} \&$ Salim Lamini ${ }^{1}$ \\ ${ }^{1}$ Council for Scientific and Industrial Research - Savanna Agricultural Research Institute, Box 46 Bawku, Ghana \\ ${ }^{2}$ Department of Horticulture, College of Agriculture and Natural Resources, Kwame Nkrumah University of \\ Science and Technology, Kumasi, Ghana \\ Correspondence: Issah Sugri, CSIR-Savanna Agricultural Research Institute, P.O. Box 46 Bawku, UER-Ghana. \\ Tel: 233-243-850-292. E-mail: isugri22@gmail.com
}

Received: June 27, 2020 Accepted: August 1, $2020 \quad$ Online Published: August 13, 2020

doi:10.5539/sar.v9n4p17 URL: https://doi.org/10.5539/sar.v9n4p17

\begin{abstract}
Sweet potato is now classified among the high-priority crops targeted at reducing food insecurity and malnutrition in many countries. Despite this growing interest, high postharvest losses caused by poor handling, physiological weight loss, sprouting, weevil (Cylas spp.) damage, and microbial decay remain a challenge. Decay losses due to tip rot and other pathogenic fungi are a challenge in Ghana. Incidence of tip rot, which is characterized by a dry decay at either or both ends of roots, is severe due to late harvesting of roots which are intended for storage. This study evaluated a series of postharvest techniques which can be integrated to extend shelf-life in small scale storage. These include harvest maturity, root tip coppicing, hot water treatment, honey waxing, and sanitizing in postharvest chemicals. Root tip coppicing significantly $(\mathrm{P}<0.001)$ reduced the incidence of tip rot across the varieties when vstored for 8 weeks, but dipping roots in different oils did not significantly $(\mathrm{P}<0.05)$ reduce tip rot incidence. Decay losses in the control and hot water treated roots were similar during the first 4 weeks after storage, but later losses were significantly severe in hot water treated roots. The range of fungi genera identified in this study are generally fungal endophytes; often symptomless in roots, but become pathogenic when conditions are favourable. Due to the thin skin of roots, mechanical injuries during harvesting and handling become infection pathways for such pathogens. Therefore, integration of best practices at each step of harvesting and postharvest handling operations can significantly minimize decay losses.
\end{abstract}

Keywords: Late harvesting, root tip rot, hot water bath, sensory quality and polysaccharide-based waxing

\section{Introduction}

Despite a growing commercial interest in both the fresh and processed sweet potato (Ipomoea batatas) products to fight food insecurity and malnutrition challenges, high postharvest losses remain a constraint to the actors in developing countries (Dandago and Gungula, 2011; Abidin et al., 2016; Sugri et al., 2017a). One cause of postharvest losses is limited or no access to cold chain facilities; an essential component to reduce physiological and microbial breakdown (Abidin et al., 2016; Sugri et al., 2017b). Traders usually attempt to sell their consignments within 4 days after harvest to minimize spoilage in domestic markets. This practice leads to seasonal glut and its associated effects on price. In general, by employing appropriate pre-storage treatments against microbial decay and sprouting, shelf-life can be extended by 6 to 12 months when stored at $12-15^{\circ} \mathrm{C}$ and $85-90 \%$ relative humidity. However, cost of cold chain facilities is beyond the capacity of smallholder growers in most parts of sub-Saharan Africa. Therefore, the growers resort to a number of traditional and improved-traditional techniques of storage to prolong shelf-life (Abidin et al., 2016; Dandago and Gungula, 2011). These include in-ground storage, heap storage, platform storage, pit storage, sand-pit method, pit under shade, and covering with grass on platforms or in baskets. In some cases, ash, soil, sawdust, and a cocktail of materials are added to reduce decay losses.

In general, decay losses caused by pathogenic fungi are a challenge during storage. The most pathogenic fungi include Fusarium oxysporum, Aspergillus niger, soft rot (Rhizopus stolonifer, R. oryzae), Java black rot (Botryodiplodia theobromae), Black rot (Ceratocystis fimbriata), Sclerotium rot (Sclerotium rolfsii), Rhizoctonia solani, Plenodomus destruens, and Penicillium spp. (Holmes and Stange, 2002; Ray and Nedunchezhiyan, 2012; Olaitan, 2012). Some pathogens such as Fusarium spp. and Macrophomina phaseolina can survive in crop 
residue and in the soil, from one season to another. Studies suggest some variations in fungi associated with rots depending on the country and agro-ecology. Earlier studies on sweet potato rots in Ghana found Aspergillus flavus, Aspergillus niger, Rhizopus stolonifer, Trichoderma viride, Fusarium oxysporum, Penicellium digitatum, Cladosporium herbarum and Aspergillus ochraceus, in that order, as most virulent (Tortoe et al., 2010). In southern Nigeria, the most pathogenic fungi were Aspergillus niger, Fusarium oxysporum, Botryodiplodia theobromae, Rhizopus stolonifer and Penicillium spp. (Olaitan, 2012). In Mississippi in the United States of America, rhizopus soft rot (Rhizopus stolonifer, R. nigricans and R. arrhizus) was reported as most destructive (Holmes and Stange, 2002). However, Ray and Nedunchezhiyan (2012), listed the most important pathogens in the order of Java black rot (Botryodiplodia theobromae), soft rot (Rhizopus oryzae), black rot (Ceratocystis fimbriata), sclerotium rot (Sclerotium rolfsii), charcoal rot (Macrophomina phaseolina), Curvularia lunata (Cochliobulus lunutus), Rhizoctonia solani, and Plenodomus destruens.

Another constraint is the high decay losses caused by tip rot, which is characterized by a visible dry decay at either or both ends of the stored roots (da Silva and Clark, 2012; Stokes et al., 2012; Arancibia et al., 2013). In Mississippi State in the USA for instance, packhouse losses due to tip rot can be as high as 6 to 59\% (Arancibia et al., 2013). Currently, the types of pathogens isolated from tip rot lesions have been inconsistent, and a relationship with field stress has been suspected (Arancibia et al., 2013). The common fungi include Fusarium solani, Macrophomina phaseolina, Lasiodiplodia theobromae, and Diaporthe batatatis. Another record found F. solani and M. phaseolina simultaneously infecting the same lesions (da Silva and Clark, 2012). In that study, F. solani and M. phaseolina were isolated from healthy roots that did not show any tip rot symptoms. These findings indicated that both fungi were present inside of symptomless roots, suggesting that they were probably fungal endophytes in such roots, and became pathogenic when conditions were favourable.

Tip rot may be common in Ghana, but farmers relate the incidence to heat stress at harvest. Farmers' routine tip rot management involves delaying the harvesting time to allow the roots to cure in-ground. At harvest, they do not cut the attached stem, with the assertion that any injury at the proximal end will exacerbate infection. However, the practice of in-ground curing is not appropriate since infestation by sweet potato weevil (Cylas spp.) and tip rot incidence can be severe if harvesting is delayed. This study evaluated a series of low-cost postharvest techniques which can be integrated to reduce decay losses in storage. These included: harvest maturity, root tip coppicing, hot water treatment, honey waxing, and sanitizing in postharvest chemical treatments.

\section{Materials and Methods}

\subsection{Experimental Procedure}

The study was conducted at the Manga Agriculture Station of the CSIR-Savanna Agricultural Research Institute in the Binduri District of the Upper East Region of Ghana. The study period was October to February, the peak harvest season, in 2016 to 2018. The study area (Binduri, Bawku, and Pusiga Districts) records the highest production of sweet potato in Ghana. The area has average temperatures of $30 \pm 5^{\circ} \mathrm{C}$ and $35 \pm 5^{\circ} \mathrm{C}$ from June to October and November to May, respectively, while relative humidity (rh) ranges from $60-80 \%$ and $25-55 \%$ within the same periods.

Four sweet potato varieties (Asamarig, Apomuden, Kuffour, and Tuskegee purple) were harvested from experimental fields in October to November each year for the study. The roots were carefully harvested to reduce bruising. They were then packed in plastic baskets and transported to a storage room. Soil particles were removed by gently brushing the root surfaces using a soft-bristled brush. Commercial grade roots (150-250g) that were as uniform as possible in size, and free of mechanical, insect or pathological injuries were selected. The sorted roots were cured under a shade for 7 days before being subjected to different storage treatments.

\subsection{Assessment of Postharvest Techniques}

\subsubsection{Root Tip Coppicing}

Three replicates of 10 roots were coppiced and dipped in 5 vegetable oils (control, shea butter, palm kernel, coconut, and olive). Coppicing involves slicing the root tips at about $3 \mathrm{~cm}$ with a sharp knife. The roots were then buried in dry sea-sand contained in plastic baskets. Decay incidence was monitored at weekly intervals for 8 weeks.

\subsubsection{Harvest Maturity and Hot Water Treatment}

Two harvest periods which depict indigenous farmers' practices in the study area were evaluated. For sweet potato planned for storage, harvesting is usually delayed to about 110 to 130 days (90-100\% leaf-fall stage); a practice referred to as in-ground curing. Such roots are usually stored without trimming the attached stems. The experimental set-up was a $4 \times 2 \times 2$ factorial in a completely randomized design. Where factor 1 consisted of 4 
varieties, factor 2 consisted of 2 harvest dates and factor 3 involved hot water treatment and control. Treatment units involved 3 replicates of 10 roots, harvested at 100 and 120 days after planting (DAP), and subjected to hot water bath at $50^{\circ} \mathrm{C}$ for $60 \mathrm{sec}$. The roots were buried in dry sea-sand contained in plastic baskets. Decay incidence was monitored at weekly intervals for 8 weeks.

\subsubsection{Postharvest Chemical Treatments}

Three replicates of 10 roots which were harvested at 100 and 120 DAP, were coppiced and subjected to different postharvest chemical treatments. The chemical treatments were hydrogen peroxide, Agrosafe (ai: Azadirachtin, neem seed oil for organic use), Sulfa $80 \%$ WP (ai: $80 \%$ Sulphur, organic fungicide at recommended rate), and Agricombi (ai: Fenitrothion (30\%) and Fenvalerate (10\%). All the chemicals are allowed for postharvest application with pre-harvest interval of 7 days. Only recommended rates provided by the manufacturers were applied. After treatment, the roots were air-dried in a storage room and buried in dry sea-sand contained in plastic baskets. Decay incidence was monitored at weekly intervals for 12 weeks.

\subsubsection{Honey Waxing}

In a similar procedure, the roots were treated with the above postharvest chemicals, waxed with honey, and buried in dry sea-sand contained in plastic baskets. Decay incidence was monitored at weekly intervals for 12 weeks.

\subsection{Data Collection}

\subsubsection{Isolation and Identification of Pathogens}

A total of 210 roots showing partial decomposition were collected from the different treatments being studied over a period of 12 weeks. The roots were washed to remove debris and other foreign materials. Portions of roots showing symptoms of rot were excised with a sterilized scalpel. With the aid of a heat sterilized forceps, the diseased tissues were excised at the point of advancing rot. The excised tissues were surface-sterilized in 5\% sodium hypochlorite solution for 5 minutes and washed in three folds of sterilized distilled water. The tissues were then blotted dry on a sterilized tissue under a Lamina flow chamber. Tissue pieces were then transferred onto $9 \mathrm{~mm}$ petri dishes containing prepared potato dextrose agar (PDA) (OXOID) amended with streptomycin sulphate to prevent saprophytic bacterial contamination. The cultures were incubated for 72 hours at $27-30^{\circ} \mathrm{C}$, during which they were observed for pathogen growth. Three days after incubation, representative cultures were obtained and sub-cultured by transferring mycelia plugs onto freshly prepared PDA to obtain pure cultures and again incubated at $27-30^{\circ} \mathrm{C}$. Pathogen identification was done by comparing morphological characteristics and microscopic structures to descriptions of Barnett and Hunter (2006).

\subsubsection{Determination of $\mathrm{Fe}, \mathrm{Zn}, \beta$-carotene, and Other Characteristics}

The determination of compositional characteristics was same as the methods described in our earlier study (Sugri et al., 2019). After harvest, 3 roots of each variety were selected for the determination of Fe, $\mathrm{Zn}, \beta$-carotene, and other characteristics. We followed recommended guides for analysis of active compounds in functional foods (Nollet and Todra, 2012), while sample preparation was done according to the procedure of (Manley, (2014) and Ikeogu et al. (2017) for rapid analysis of carotenoids in fresh roots using near infrared spectrometer. Working samples of $360 \mathrm{~g}$ each, consisting $60 \mathrm{~g}$ of sweet potato flesh obtained from the proximal ends, were dried in a vacuum freeze dryer (YK-118 Vacuum Freeze Drier, True Ten Industrial Co. Ltd., USA). The dried samples were milled using a Wiley Mini Mill and packed in whirlpack plastic bags. Analysis for Fe, Zn, $\beta$-carotene and other components was then conducted using the Near Infrared Reflectance Spectrophotometer (NIRS) (NIRS XDS Process Analyzer-Micro Bundle Metrohm Company, USA). The NIRS procedure allows for non-destructive measurement of powders, slurries, and liquid samples directly in a process line, granulator, dryer or reaction vessel (Manley, 2014). Up to 4 probes and flow-cells were connected to the analyzer, and with the cuvette filled $2 \mathrm{~g}$ of the milled samples and covered with a cap. After scanning samples, the IsI scan software was used to determine the quality attributes ( $\beta$-carotene, dry matter, protein, starch, glucose, fructose, sucrose, Fe, and Zn).

\subsubsection{Sensory Analysis}

At the terminal period of storage, 120 regular consumers were engaged in a consumer effective test to measure acceptance of the stored roots. Acceptance is defined as a feature of experience characterized by a positive attitude, or general preference for a specific product. Generally, it is recommended that a representative sample of consumers were selected for the target population. The panel were not trained, but were selected at random to represent potential consumers. The panel were selected on the basis of demographic criteria such as age, sex, education, income, nationality, race, and geographical location among others (Fletcher et al., 1997). Root samples were washed, peeled, and diced into lamellas of $\sim 4 \times 6 \mathrm{~cm}$ for frying. No additive nor salt was added. 
Deep-fat frying was done by using vegetable oil at boiling point. Coded samples were then presented in serving plates to the panel. Different categories of panel, age 20-60 years, drawn from the Manga Agriculture Station and communities in the Binduri District were engaged. The samples were assessed for sweetness, flavour, texture, mouth-feel, and overall acceptability using a score of 1 to 5 ; where best score of $1=$ very good for the trait being assessed, up to worse score of $5=$ not acceptable for consumption.

\subsubsection{Data Analysis}

Factorial analysis of variance (ANOVA) procedure was used for testing the effect of treatments using GenStat ${ }^{\circledR}$ statistical program (12 ${ }^{\text {th }}$ edition). Fischer Least Significant Difference (LSD) method was used to segregate treatments which were significantly different at $5 \%$ level of probability.

\section{Results and Discussion}

\subsection{Characteristics of Varieties}

Table 1 describes some compositional characteristics (dry matter, protein, starch, glucose, fructose, sucrose, Fe, and $\mathrm{Zn}$ ) of roots harvested at 120 days after planting. Compositional changes with prolonged storage was not followed due to logistic challenges. Apomuden and Kuffour are improved orange-fleshed varieties which are widely cultivated by farmers. Tuskegee purple was an advance genotype being assessed in on-farm trials for release to farmers due to its high anthocyanin level.

Table 1. Description and compositional characteristics (dry matter, protein, starch, glucose, fructose, sucrose, Fe, and $\mathrm{Zn}$ ) of sweet potato varieties harvested at 120 days after planting

\begin{tabular}{|c|c|c|c|c|c|c|c|c|c|c|c|c|}
\hline \multirow[t]{2}{*}{ Variety } & \multicolumn{12}{|c|}{ Detail characteristics of varieties } \\
\hline & Status & $\begin{array}{l}\text { Skin } \\
\text { colour }\end{array}$ & $\begin{array}{l}\text { Flesh } \\
\text { colour }\end{array}$ & $\begin{array}{l}\text { Dry } \\
\text { matter } \\
(\%) \\
\end{array}$ & $\begin{array}{l}\text { Protein } \\
(\%)\end{array}$ & $\begin{array}{l}\text { Starch } \\
(\%)\end{array}$ & $\begin{array}{l}\text { Glucose } \\
(\%)\end{array}$ & $\begin{array}{l}\text { Sucrose } \\
(\%)\end{array}$ & $\begin{array}{l}\text { Fructose } \\
(\%)\end{array}$ & $\begin{array}{l}\mathrm{Fe} \\
(\mathrm{mg} / 100 \mathrm{~g})\end{array}$ & $\begin{array}{l}\mathrm{Zn} \\
(\mathrm{mg} / 100 \mathrm{~g})\end{array}$ & B-Carotene \\
\hline Asamarig & Farmer & Pink, white & white & 37.6 & 3.1 & 61.2 & 10.8 & 9.8 & 7.3 & 1.8 & 0.8 & 4.4 \\
\hline Apomuden & Improved & Copper & Orange & 25.7 & 3.1 & 52.7 & 14.4 & 7.7 & 9.9 & 2.2 & 1.1 & 31.6 \\
\hline Kuffour & Improved & Orange & Orange & 26.6 & 3.1 & 52.9 & 14.3 & 7.7 & 9.8 & 2.2 & 1.0 & 31.9 \\
\hline $\begin{array}{l}\text { Tuskegee } \\
\text { purple }\end{array}$ & $\begin{array}{l}\text { Advance } \\
\text { genotype }\end{array}$ & $\begin{array}{l}\text { Dark } \\
\text { purple }\end{array}$ & $\begin{array}{l}\text { Dark } \\
\text { purple }\end{array}$ & 40.3 & 4.3 & 60.3 & 7.2 & 13.1 & 4.6 & 2.3 & 1.0 & 0.0 \\
\hline Grand mean & & & & 32.5 & 3.4 & 56.8 & 11.7 & 9.5 & 7.9 & 2.1 & 1.0 & 22.6 \\
\hline Significance level & & & & 0.001 & 0.01 & 0.001 & 0.001 & 0.001 & 0.001 & 0.001 & 0.001 & 0.001 \\
\hline $\mathrm{CV}(\%)$ & & & & 3.3 & 9.8 & 2.3 & 7.0 & 7.3 & 7.5 & 4.5 & 5.2 & 8.8 \\
\hline
\end{tabular}

\subsection{Effect of Tip Coppicing}

Tip coppicing significantly $(\mathrm{P}<0.001)$ reduced the incidence of tip rot across the varieties $(\mathrm{P}<0.01)$ when stored for 8 weeks (Table 2). The effect of variety $\times$ coppicing $\times$ maturity interaction was not significant $(P<0.05)$. The incidence of tip rot at 8 WAS were 5.9\% in coppiced roots and 6.9\% in intact roots. Dipping the coppiced roots in different oils did not significantly $(\mathrm{P}<0.05)$ reduce tip rot incidence. Dipping the coppiced roots in different vegetable oils showed a reduction of 5.7 to $5.8 \%$ tip rot incidence as compared to the control (7.2\%) at 8 WAS. Tip rot occurred at the proximal end of roots as a small sunken and irregular lesion encircled by a sharp border (Figure 1c). Symptoms are manifested as a restricted lesion at or close to the tip of roots. Symptoms may appear after 2 to 4 WAS. Usually, the necrosis expands internally and invade root flesh asymmetrically with little or no external symptoms (Figure 1d). 


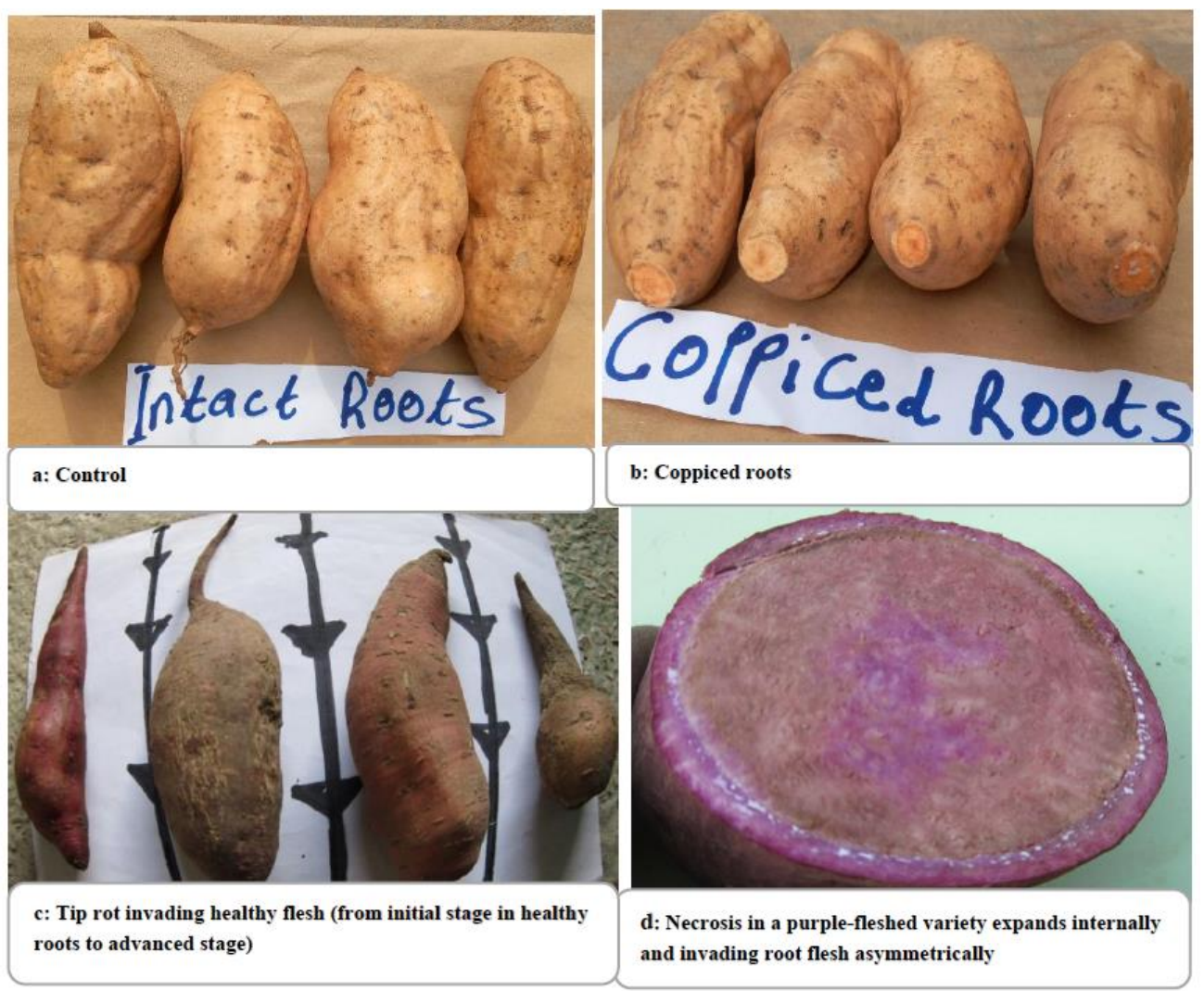

Figure 1a-d. Tip coppicing, characteristics and symptoms of tip rot disease invasion

Table 2. Tip rot incidence as influenced by coppicing, dipping in oil, and variety

\begin{tabular}{llll}
\hline \multirow{2}{*}{ Factor } & \multicolumn{3}{c}{ Tip rot incidence (\%) } \\
\cline { 2 - 4 } & 2 weeks & 4 weeks & 8 weeks \\
\hline Coppicing & & & \\
\hline Intact root & $4.1(10)$ & $5.6(22)$ & $6.9(35.6)$ \\
Coppiced root & $3.6(7)$ & $4.7(14)$ & $5.9(23.5)$ \\
Significance level & 0.01 & 0.01 & 0.001 \\
LSD $_{(\mathrm{P}<0.05)}$ & 0.3 & 0.5 & 0.5 \\
\hline Dipping in oil & & & \\
\hline No wax & $4.0(10)$ & $5.4(19.7)$ & $6.7(33)$ \\
Coconut & $3.9(8.7)$ & $5.2(18.4)$ & $6.3(29)$ \\
Olive oil & $3.8(8.4)$ & $4.9(16)$ & $6.2(28.3)$ \\
Palm kernel oil & $3.9(8.9)$ & $5.3(19)$ & $6.2(28.5)$ \\
Shea butter & $3.7(7.7)$ & $5.0(17)$ & $6.3(29)$ \\
Significance level & $\mathrm{ns}$ & $\mathrm{ns}$ & $\mathrm{Ns}$ \\
\hline Variety & & & \\
\hline Asamarig & $3.4(6)$ & $4.6(14.6)$ & $6.1(26.7)$ \\
Apomuden & $4.3(11)$ & $5.6(21.6)$ & $6.6(31.4)$ \\
Kuffour & $3.9(8.4)$ & $5.1(18)$ & $6.5(30.7)$ \\
Tuskegee purple & $4.0(9)$ & $5.1(18)$ & $6.4(29.5)$ \\
Significance level & 0.001 & 0.01 & 0.01 \\
LSD (P<0.05) & 0.3 & 0.4 & 0.2 \\
CV(\%) & 9.9 & 11.3 & 5.4 \\
\hline
\end{tabular}

CV: Coefficient of variation of three replicates.

Incidence data was managed by square root transformation.

Percent incidence data in parenthesis were not transformed 


\subsection{Fungi Associated with Rots}

Isolation and identification of pathogens associated with decaying roots found 7 most recurring fungi genera (Figure 2). These included: Rhizopus stolonifer, Macrophomina phaseolina, Fusarium spp., Mucor racemosus, Aspergillus spp., Botryodiplodia theobromae and Penicillium spp. The pathogens recorded in the study were similar to those reported by Tortoe et al. (2010), Holmes and Stange (2002), Prange et al. (2006), and Olaitan (2012), however, variations exist in pathogens associated with decaying roots. In some cases, no pathogen was observed in lesions (da Silva and Clark, 2012; Stokes et al., 2012; Arancibia et al., 2013). Other pathogens such as Lasiodiplodia theobromae and Diaporthe phaseolorum have been isolated from lesions (da Silva and Clark, 2012; Stokes et al., 2012). In a study, pre-harvest foliar applications of ethephon was reported to trigger a response that increased the incidence of tip rot disorder (Arancibia et al., 2013). The study recommended curing at optimal conditions to reduce tip rot incidence. Bruised or cut roots readily become colonized by propagules of pathogens associated with the surface and those from adjacent infected roots (Ray, 2010; Ray and Nedunchezhiyan, 2012). Infection can be reduced by minimizing mechanical injuries at handling and harsh environmental conditions.

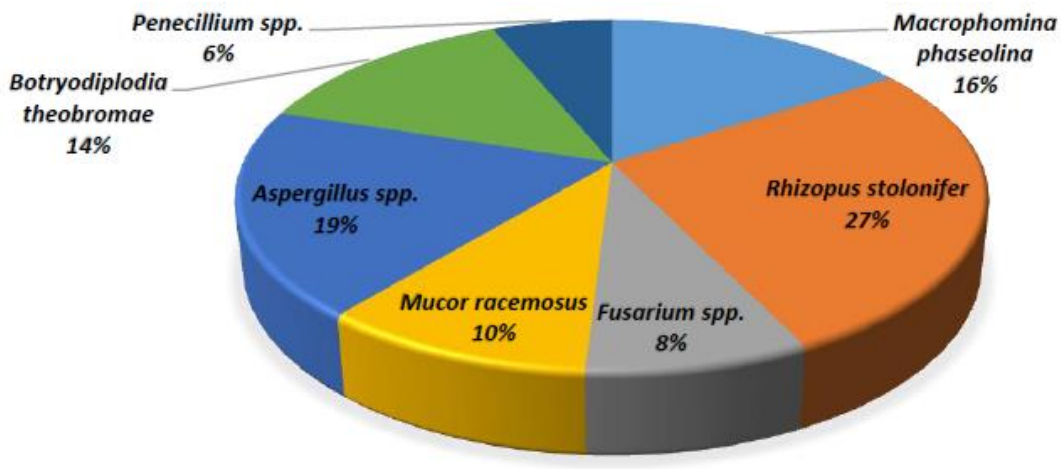

Figure 2. Incidence of pathogenic fungi associated with decaying sweet potato roots

\subsection{Effects of Harvest Maturity and Hot Water Treatment}

Harvest maturity significantly $(\mathrm{P}<0.001)$ influenced decay losses across the varieties during 8 WAS. Sanitizing roots in hot water did not significantly $(\mathrm{P}<0.05)$ reduce decay incidence during 8 WAS. Overall, decay losses were similar in the control and hot water treated roots during the first 4 WAS, but later losses were significantly $(\mathrm{P}<0.001)$ severe in hot water treated roots (Figure 3a). By 8 WAS, roots harvested at 100 DAP showed significantly $(\mathrm{P}<0.001)$ lower decay losses $(32.4 \%)$ compared to 120 DAP $(39.5 \%)$ (Figure $3 b)$. The effect of harvesting date $\times$ hot water treatment followed a similar trend (Figure $3 \mathrm{c}$ ). No significant differences $(\mathrm{P}<0.05)$ were recorded in the first 4 weeks, but decay losses varied significantly $(\mathrm{P}<0.01)$ by 8 WAS, where root harvested at 120 DAP and treated with hot water showed higher losses.

Studies have demonstrated that hot water treatment (by immersion, brushing or rinsing) offers a promising non-chemical option for use in many horticultural crops (Fallik, 2004; Prange et al., 2006). However, just a little information exist for sweet potato. Since this is a non-chemical technology, there is no governmental approval requirement before being accepted for use by growers. A study on the effects of hot water bath $\left(55^{\circ} \mathrm{C} / 60 \mathrm{sec}\right.$. $)$ followed by postharvest treatments ('Bio-health' and 'Clean root') showed reduced decay losses during 2 weeks of storage (El-Sayed et al., 2013). This study could not establish the potential of hot water treatment for storage beyond 4 weeks at ambient conditions. The effects of harvesting date on shelf-life may vary depending on season and location. For instance, early harvesting may reduce incidence and damage of sweet potato weevils, which has a direct effect on shelf-life (Mansaray et al., 2013). Another view relates to increases in soil temperatures in the dry season which may accelerate both physiological and microbial damage (Parr et al., 2014). However, if good agronomic practices are observed during production, delay in harvesting from 2-3 week, usually known as in-ground, has advantages on shelf-life. 


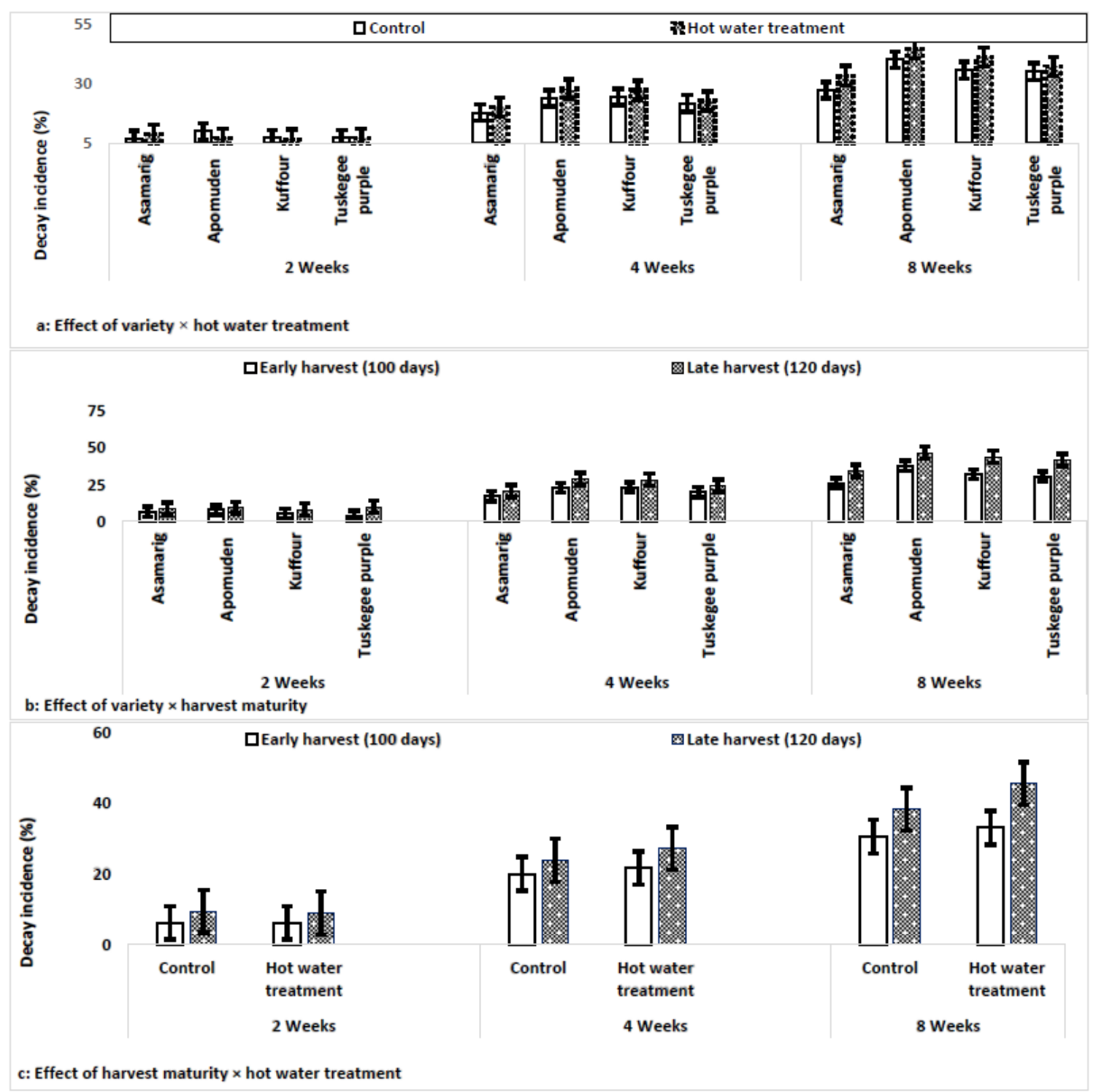

Figure 3a-c. Effects of a) hot water treatment $\times$ variety, $b$ ) harvest maturity $\times$ variety, and c) hot water $\times$ harvest maturity on decay losses in 4 sweet potato varieties stored for 8 weeks

Data represents the means of three replications of 10 roots subjected to ANOVA; Error bars represent standard error of three replications.

\subsection{Effect of Postharvest Chemical Treatments}

At all periods of storage, decay losses were significantly influenced by variety, harvest maturity, and chemical treatments (Table 3). Sanitizing roots in chemical treatments significantly $(\mathrm{P}<0.001)$ reduced decay losses across the varieties. Harvest maturity $\times$ chemical treatment interaction showed significant $(\mathrm{P}<0.01)$ reduction in decay losses when roots were harvested at 100 DAP compared to late harvest at 120 DAP. Apomuden was the most susceptible to decay losses compared to the other varieties. Reduction in decay losses was in order of Agricombi (7.3\%), Agro safe (7.5\%), Sulfa 80 WP (7.8\%), Hydrogen peroxide (7.9\%), and control (8.6\%). 
Table 3: Decay losses as affected by harvest maturity, chemical treatments, and variety

\begin{tabular}{|c|c|c|c|}
\hline \multirow[b]{2}{*}{ Treatments } & \multicolumn{3}{|c|}{ Decay losses (\%) at } \\
\hline & 4 Weeks & 8 Weeks & 12 Weeks \\
\hline \multicolumn{4}{|l|}{ Harvest maturity } \\
\hline Early (100 days) & $4.3(11.6)^{\mathrm{a}}$ & $5.9(23.8)^{\mathrm{a}}$ & $7.5(42.9)^{\mathrm{a}}$ \\
\hline Late (120 days) & $5.1(17.0)^{\mathrm{b}}$ & $6.9(34.9)^{\mathrm{b}}$ & $8.1(51.3)^{b}$ \\
\hline Significance level & 0.001 & 0.01 & 0.001 \\
\hline $\operatorname{LSD}_{(\mathrm{p}<0.05)}$ & 0.23 & 0.23 & 0.18 \\
\hline \multicolumn{4}{|c|}{ Chemical treatments } \\
\hline Control & $5.1(16.6)^{\mathrm{b}}$ & $7.1(36.0)^{\mathrm{c}}$ & $8.6(57.7)^{\mathrm{c}}$ \\
\hline Hydrogen peroxide & $4.8(15.1)^{\mathrm{ab}}$ & $6.5(29.4)^{b}$ & $7.9(46.4)^{b}$ \\
\hline Agrosafe & $4.6(13.1)^{\mathrm{ab}}$ & $6.1(26.0)^{\mathrm{ab}}$ & $7.5(42.5)^{\mathrm{ab}}$ \\
\hline Sulfa $80 \mathrm{WP}$ & $4.7(14.9)^{\mathrm{ab}}$ & $6.3(30.0)^{\mathrm{ab}}$ & $7.8(47.1)^{b}$ \\
\hline Agricombi & $4.3(11.4)^{\mathrm{a}}$ & $5.8(24.9)^{\mathrm{a}}$ & $7.3(41.3)^{\mathrm{a}}$ \\
\hline Significance level & 0.001 & 0.001 & 0.001 \\
\hline $\mathrm{LSD}_{(\mathrm{p}<0.05)}$ & 0.36 & 0.37 & 0.29 \\
\hline \multicolumn{4}{|l|}{ Variety } \\
\hline Asamarig & $4.0(9.3)^{\mathrm{a}}$ & $5.5(18.6)^{\mathrm{a}}$ & $7.4(40.4)^{\mathrm{a}}$ \\
\hline Apomuden & $5.2(18.3)^{\mathrm{c}}$ & $6.8(36.3)^{\mathrm{c}}$ & $7.9(49.3)^{b}$ \\
\hline Kuffour & $4.8(14.8)^{\mathrm{b}}$ & $6.5(29.8)^{b}$ & $7.9(48.4)^{b}$ \\
\hline Tuskegee purple & $4.8(14.7)^{\mathrm{b}}$ & $6.7(32.7)^{\mathrm{bc}}$ & $8.0(49.8)^{\mathrm{b}}$ \\
\hline Significance level & 0.001 & 0.001 & 0.001 \\
\hline $\operatorname{LDS}_{(\mathrm{p}<0.05)}$ & 0.32 & 0.33 & 0.26 \\
\hline $\mathrm{CV}(\%)$ & 4.3 & 6.3 & 7.8 \\
\hline
\end{tabular}

Incidence data was managed by square root transformation; Percentage incidence data in parenthesis were not transformed.

The chemical treatments applied in this study were safe for postharvest use. Except for Agricombi (ai: Fenitrothion (30\%) and Fenvalerate (10\%), the other chemicals are permitted for use in organic produce (Prange et al., 2006). Agrosafe in particular, which is made from neem seed oil (ai: Azadirachtin) with a pre-harvest interval of 7 days, could be considered as a broad spectrum bio-pesticide against weevils and pathogenic fungi. Neem products have insecticidal, repellent, anti-feedant, sterilizing, and growth inhibition effects against several species of insects (Obeng-Ofori and Sackey, 2003), including control of several fungal diseases. It must be noted however that, postharvest chemical treatments are now generally avoided to prevent spoilage, as it may impart residue problems (Ray and Nedunchezhiyan, 2012). There is divided opinion though on the use of chemical treatments, particularly in developing countries where high losses and food insecurity exist. Presumably, the lack of strict food safety regulations in such countries may lead to indiscriminate use of pesticides which can have dire consequences on environmental and human health. In all cases, responsible use of agro-chemicals at recommended dose, and observing the safe application intervals should be strictly observed.

\subsection{Effect of Honey Waxing ( $H W)$}

During storage for 12 weeks, significant effects of HW ( $\mathrm{P}<0.001)$, chemical treatment $(\mathrm{P}<0.001)$, and HW $\times$ chemical treatments $(\mathrm{P}<0.001)$ were recorded. Roots coated with HW showed minimal decay losses $(24 \%)$ by 12 WAS compared to the control (37.1\%) (Figure 4a). Across the varieties, roots coated with honey wax recorded low decay incidence compared to the control, but relative susceptibility of the varieties to decay followed a similar pattern (Figure 4b). Roots which were sanitized with chemical treatments and waxed with honey recorded the least losses of 22.3 to $30.3 \%$ at 12 WAS compared to the control (32.9 to 69.2\%) (Figure 4c). 


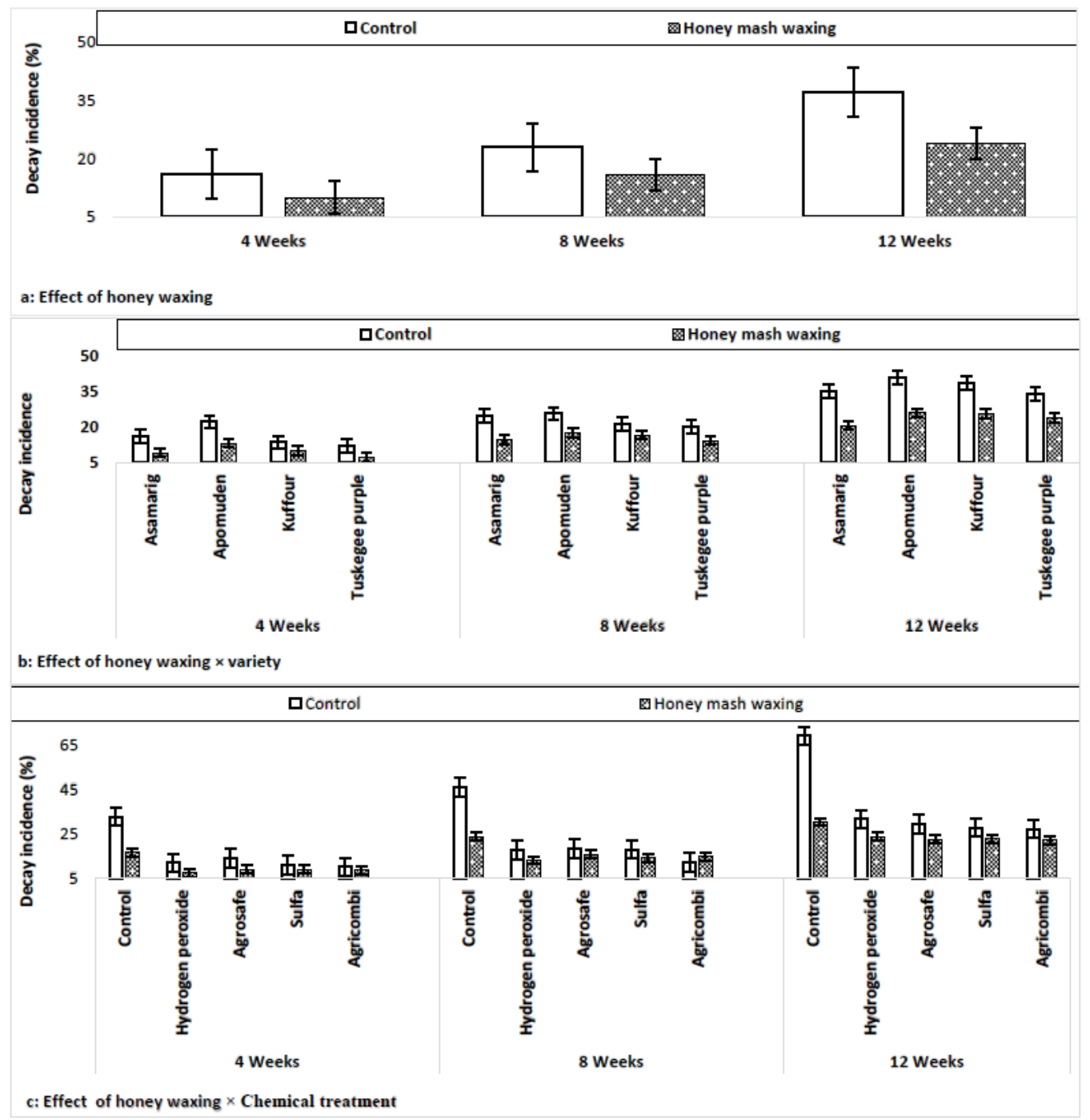

Figure 4a-c. Effects of a) honey mash waxing, b) variety $\times$ honey mash waxing, and c) honey mash waxing $\times$ chemical treatment on decay losses in 4 sweet potato varieties stored for 12 weeks

Data represents the means of three replications of 10 roots; ANOVA was conducted using mean of three replicates; Error bars represent standard error of three replications.

\subsection{Sensory Evaluation}

The socio-demographic characteristics (age, gender and education) of the sensory panel were described (Table 4). The panel nether detected the differences between fried samples of honey-coated and control nor differences between the 5 postharvest chemical treatments and control. Overall, $89.1 \%$ of the panel scored the samples from acceptable to highly acceptable for consumption. The trend in Figures $5 \mathrm{a}$ and $\mathrm{b}$ showed that consumer acceptance was largely influenced by an amalgam of sensory descriptors and gender. Consistently, high sweetness, followed by soft versus hard texture, were the domineering sensory descriptors across gender groups (Figure 5a). For Asamarig and Apomuden, descriptors such as highly sweet, soft texture and strong flavour were the critical sensory traits to the panel. However, this was different in Tuskegee purple, where hard texture, dry matter and less sweet were the critical attributes (Figure 5b). 
Table 4. Socio-demographic characteristics of sensory panelist, and penal sensory acuity (\%)

\begin{tabular}{lllll}
\hline Characteristics & Description & Male & Female & Total \\
\hline \multirow{4}{*}{ Age } & $20-35$ & 60.3 & 38.7 & 49.2 \\
& $36-45$ & 27.6 & 45.3 & 36.7 \\
Education & $46-60$ & 12.1 & 16.1 & 14.2 \\
& No formal education & 29.3 & 32.3 & 30.8 \\
\multirow{5}{*}{ Preference for } & Basic & 22.4 & 27.4 & 25.0 \\
& Secondary & 19 & 25.8 & 22.5 \\
& Tertiary & 29.3 & 14.5 & 21.7 \\
Acceptability rating & Stored roots & 36 & 58.1 & 47.5 \\
& Fresh roots & 63 & 41.9 & 52.5 \\
& Not acceptable & 3.4 & - & 1.7 \\
& Poorly acceptable & 10.3 & 8.1 & 9.2 \\
& Acceptable & 41.3 & 37.1 & 39.2 \\
Panel ability to detect & Very acceptable & 31.00 & 35.5 & 33.3 \\
differences between: & Highly acceptable & 13.8 & 19.9 & 16.7 \\
& Cored $\times$ fresh roots & Very sensitive & 100.0 \\
& Different $\times$ waxed roots & Not detectable & 100.0 \\
& & Not detectable & 100.0 \\
\hline
\end{tabular}

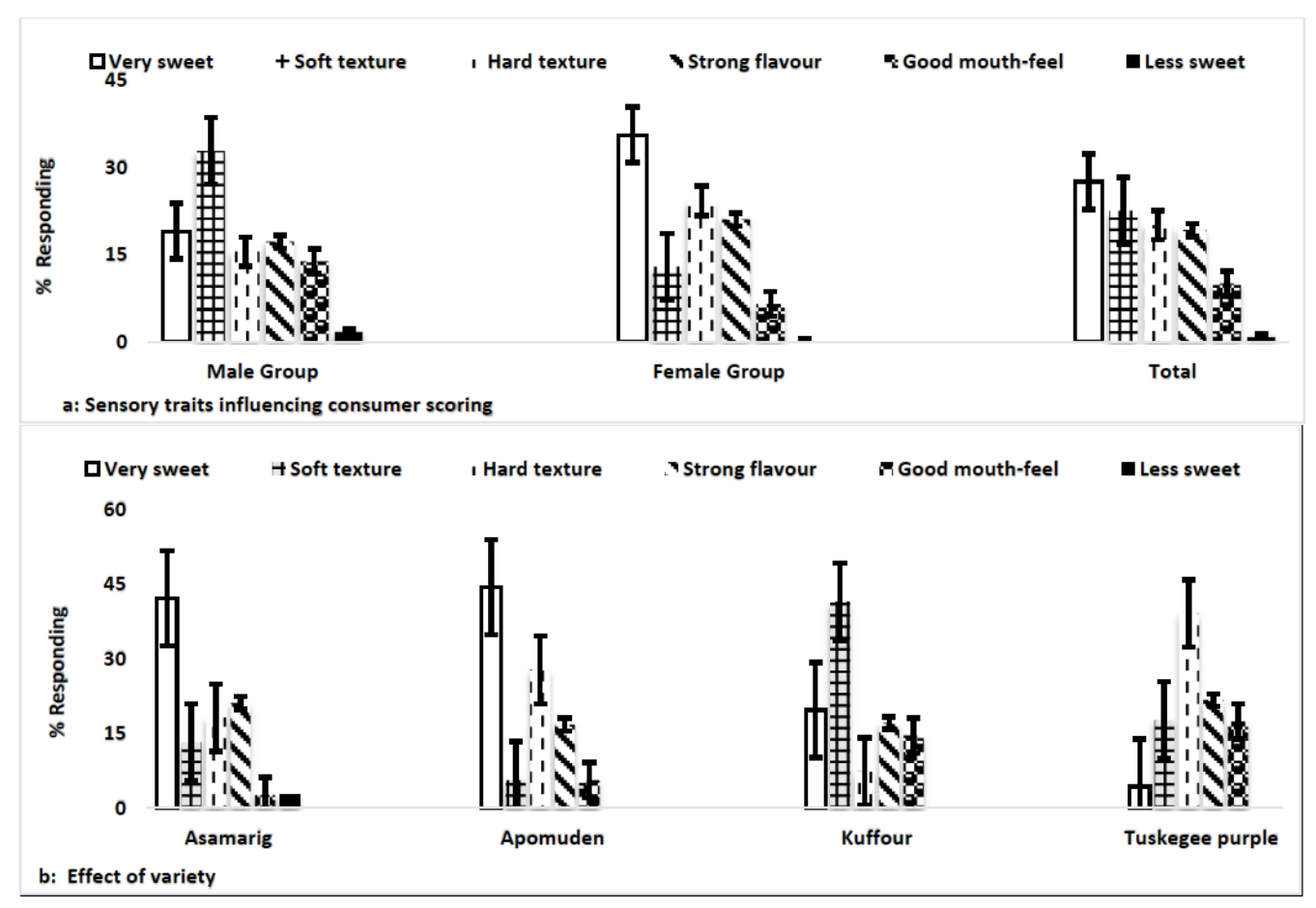

Figure 5a and b: Consumer acceptance of sweet potato roots subjected to different storage treatments

Sweet potato shelf-life is influenced by an interaction of field production practices, postharvest handling, and type of postharvest treatments applied (Ray and Nedunchezhiyan, 2012; da Silva and Clark, 2013; Adu-Kwarteng et al., 2014). Some of the pre-harvest factors include type of variety, soil type, time of planting and harvesting, maturity, fertilizer type, and pests and disease infestation. For instance, poor agronomic practices and environmental stress such as drought may predispose the roots to physiological disorders and microbial attack (da Silva and Clark, 2013). Whereas poor postharvest handling practices and storage conditions may exacerbate decay losses. Most farmers utilize traditional storage methods and vessels without applying any postharvest treatment. Integrated use of both indigenous and improved practices should be promoted substantially to reduce storage losses. For instance, curing by defoliation or dehaulming at 10 to 14 days before 
harvest has been recommended to reduced weevil infestation, fungal decay, and mechanical damage during handling (van Oirschot et al., 2006; Sugri et al., 2019). Additional advantages of dehaulming include increased sensorial qualities Parmar et al. (2017), and compositional characteristics such as total soluble solids, $\beta$-carotene, $\alpha$-amylase activity, and dry matter content (Sugri et al., 2019).

\section{Conclusion}

As we integrate best production techniques to achieve higher root yield, auxiliary operations such as storage and processing should also be improved. Postharvest deterioration is undoubtedly the most economically costly to growers because all other expenses on production, harvesting, and storage have already been incurred. This study evaluated a series of low-cost postharvest techniques and treatments which can be employed to reduce sweet potato storage losses. Root tip coppicing in particular can reduce tip rot incidence; a major cause of decay losses in sweet potato storage. Although a little labour-intensive, this method when integrated with dehaulming can significantly prolong shelf-life. In addition, sanitizing roots in appropriate postharvest chemicals such as Agrosafe (ai: Azadirachtin, neem seed oil for organic use) and honey coating exhibited significant potential for use by smallholders; with less than $25 \%$ decay losses during 12 weeks of storage. Other commercial-based polysaccharide waxes can be assessed in future studies. The possible use of honey waxing is significant in view of renewed interest in edible coatings to preserve both fresh and fresh-cut horticultural produce for domestic, export, and organic markets. Much extended shelf-life is expected when storage conditions approach optimum $\left(\sim 12-15^{\circ} \mathrm{C}\right.$ and $\left.85-90 \% \mathrm{rh}\right)$.

\section{Declarations}

\section{Consent for publication}

All authors consent to the publication of this manuscript.

\section{Competing interest}

The authors declare no competing interest for this manuscript.

\section{Availability of supporting data and materials}

The data tools and data sets for analysis are available from the corresponding author on request.

\section{Funding}

The authors received no direct funding for this research.

\section{References}

Abidin, P. E., Kazembe, J., Atuna, R. A., Amagloh, F. K., Asare, K., Dery, E. K., \& Carey, E. E. (2016). Sand storage, extending the shelf-life of fresh sweet potato roots for home consumption and market sales. Journal of Food Science and Engineering, 6, 227-236. https://doi.org/10.17265/2159-5828/2016.04.005

Adu-Kwarteng, E., Sakyi-Dawson, E. O., Ayernor, G. S., Truong, V., Shih, F. F., \& Daigle, K. (2014). Variability of sugars in staple-type sweet potato (Ipomoea batatas) cultivars: the effects of harvest time and storage. International Journal of Food Properties, 17, 410-420. https://doi.org/10.1080/10942912.2011.642439

Arancibia, R. A., Main, J. L., \& Clark, C. A. (2013). Sweetpotato tip rot incidence is increased by preharvest applications of Ethephon and reduced by curing. HortTechnology, 23(3), 288-293. https://doi.org/10.21273/HORTTECH.23.3.288

Barnett, H. L., \& Hunter, B. B. (2006). Illustrated genera of imperfect fungi. 4th Edition. The American Phytopathological Society, St. Paul Minnesota.

Dandago. M. A., \& Gungula, D. T. (2011). Effects of various storage methods on the quality and nutritional composition of sweet potato (Ipomoea batatas L.) in Yola Nigeria. International Food Research Journal, 18, 271-278.

da Silva, W. L., \& Clark, C. A. (2012). Infection of sweetpotato by fungal end rot pathogens prior to harvest. (Abstr.) Phytopathology, 102, S2.2-S2.3.

da Silva, W. L., \& Clark, C. A. (2013). Infection of sweet potato by Fusarium solani and Macrophomina phaseolina prior to harvest. Plant Diseases, 97, 1636-1644. http://dx.doi.org/10.1094/PDIS-05-13-0514-RE

El-Sayed, S. F., El-Helaly, M. A., Emam, M. S., \& Abdel-Ghaffa, M. A. (2013). Effect of some post-cold storage treatments on shelf life of sweet potato roots. Journal of Horticultural Science and Ornamental Plants, 5(3), 160-170. http://dx.doi.org/10.5829/idosi.jhsop.2013.5.3.1124 
Fallik, E. (2004). Pre-storage hot water treatments (immersion, rinsing and brushing). Postharvest Biology and Technology, 32, 125-134. https://doi.org/10.1016/j.postharvbio.2003.10.005

Fletcher, S. M., Resurrection, A. V. A., \& Misra, S. K. (1997). Measuring and modelling consumer acceptance. In R. L. Shewfelt \& S. E. Prussia (Eds.), Postharvest handling: A system approach (pp. 149-166). Acad. Press Inc., New York. https://doi.org/10.1016/B978-0-08-092576-9.50013-6

Holmes, G. J., \& Stange, R. R. (2002). Influence of wound type and storage duration on susceptibility of sweetpotatoes to Rhizopus soft rot. Plant Diseases, 86, 345-348. https://doi.org/10.1094/PDIS.2002.86.4.345

Ikeogu, U. N., Davrieux, F., Dufour, D., Ceballos, H., Egesi, C. N., \& Jannink J-L. (2017). Rapid analyses of dry matter content and carotenoids in fresh cassava roots using a portable visible and near infrared spectrometer (Vis/NIRS). PLoS One, 12(12), e0188918. https://doi.org/10.1371/journal.pone.0188918

Manley, M. (2014). Near-infrared spectroscopy and hyperspectral imaging: non-destructive analysis of biological materials. Chemical Society Review, 43, 8200-8214. https://doi.org/10.1039/C4CS00062E

Mansaray, A., Sundufu, A. J., Yilla, K., \& Fomba, S. N. (2013). Evaluation of cultural control practices in the management of sweetpotato weevil (Cylas puncticollis) Boheman (Colepotera: Curculionidae). QScience Connect, 44. http://dx.doi.org/10.5339/connect.2013.44

McCleary, B. V., McNally, M., Monaghan, D., \& Mugford, D. C. (2002). Measurement of $\alpha$-amylase activity in white wheat flour, milled malt and microbial enzyme preparations using ceralpha assay: collaborative study. Journal of AOAC International, 85, 1096-1102. https://doi.org/10.1093/jaoac/85.5.1096

Nollet, L. M. M., \& Todra, F. (2012). Handbook of Analysis of Active Compounds in Functional Foods. CRS Press Taylor and Francis Group. LLC, 600 Broken Sound Parkway, NW Suite 300 Boca Raton FL USA, pp. 195-219. https://doi.org/10.1201/b11653

Obeng-Ofori, D., \& Sackey, J. (2003). Field evaluation of non-synthetic insecticides for the management of insect pests of okra (Abelmoschus esculentus (L.) Moench) in Ghana. Ethiopia Journal of Science, 26(2), 145-150. https://doi.org/10.4314/sinet.v26i2.18210

Olaitan, O. O. (2012). Bio-deterioration of sweet potato (Ipomoea batatas Lam) in storage, inoculation-induced quality changes, and control by modified atmosphere. Journal of Applied Science and Environmental Management, 16(2), 189-193.

Parmar, A., Kirchner, S. M., Sturm, B., \& Hense, O. (2017). Pre-harvest curing: effects on skin adhesion, chemical composition and shelf-life of sweetpotato roots under tropical conditions. East Africa Agriculture and Forestry Journal, 82(2-4), 130-143. https://doi.org/10.1080/00128325.2017.1340141

Parr, M. C., Ntonifor, N. N., \& Jackai, L. E. (2014). Effect of planting dates on the population dynamics of Cylas puncticollis and sweet potato storage roots damage in South Western Cameroon. Journal of Biology, Agriculture and Healthcare, 4(18), 41-48.

Prange, R. K., Ramin, A. A., Daniels-Lakes, B. J., Delong, J. M., \& Braun, P. G. (2006). Perspectives of postharvest biopesticide and storage technologies for organic produce. HortScience, 41(2), 301-303. https://doi.org/10.21273/HORTSCI.41.2.301

Ray, R. C., \& Nedunchezhiyan, M. (2012). Postharvest fungi rots of sweet potato in tropics and control measures. Fruit, Vegetables, Cereal Science and. Biotechnology, 6(1), 134-138.

Stokes, C. E., Woolfolk, S. W., Arancibia, R. A., \& Baird. R. E. (2012). Diversity, densities, and distribution of microbial communities in sweetpotato end/tip rot diseases. HortScience, 47, S47-S48.

Sugri, I., Maalekuu, B. K., Kusi, F., \& Gaveh, E. (2017a). Quality and shelf-life of sweet potato as influenced by storage and postharvest treatments. Trends in Horticultural Research, 7(1), 1-10. https://doi.org/10.3923/thr.2017.1.10

Sugri, I., Maalekuu, B. K., Gaveh, E., \& Kusi, F. (2017b). Sweet potato value chain analysis reveals opportunities for increased income and food security in northern Ghana. Advances in Agriculture, 2017, 14. https://doi.org/10.1155/2017/8767340

Sugri, I., Maalekuu, B. K., Gaveh, E., \& Kusi, F. (2019). Compositional and shelf-life indices of sweet potato are significantly improved by pre-harvest dehaulming. Annals of Agricultural Sciences 64, 113-120 https://doi.org/10.1016/j.aoas.2019.03.002 
Tortoe, C., Obodai, M., \& Amoa-Awua, W. (2010). Microbial deterioration of white variety sweet potato (Ipomoea batatas) under different storage structures. International Journal of Plant Biology, $1,10$. https://doi.org/10.4081/pb.2010.e10

van Oirschot, Q. E. A., Rees, D., \& Aked, J. (2006). Sweet potato cultivars differ in efficiency of wound healing. Postharvest Biology and Technology, 42(1), 65-74. https://doi.org/10.1016/j.postharvbio.2006.05.013

\section{Copyrights}

Copyright for this article is retained by the author(s), with first publication rights granted to the journal.

This is an open-access article distributed under the terms and conditions of the Creative Commons Attribution license (http://creativecommons.org/licenses/by/3.0/). 